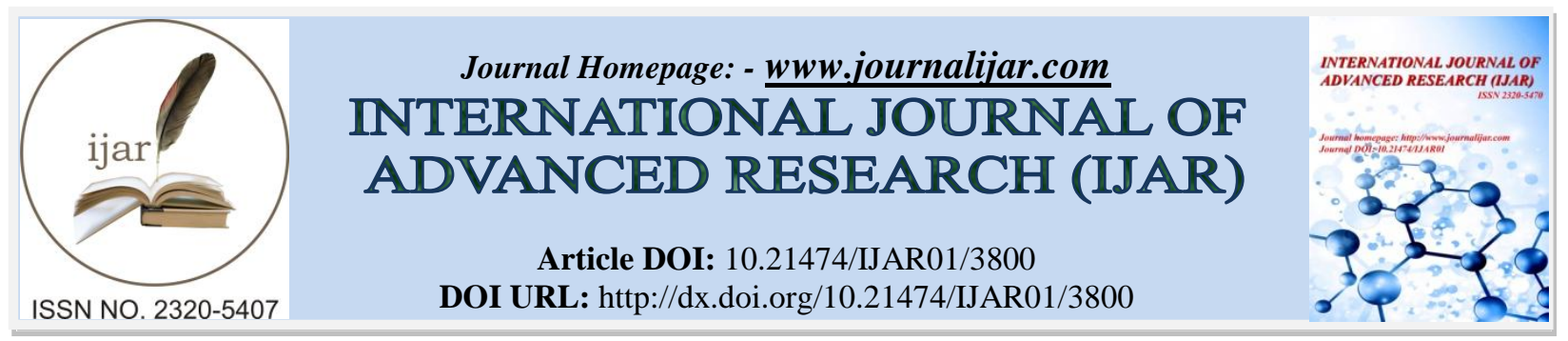

RESEARCH ARTICLE

\title{
A KINETIC STUDY OF RUBAZOIC ACID FORMATION DERIVED FROM 4-AMINO-1(4- SULPHOPHENYL) 3-METHYL-2-PYRAZOLIN-5-ONE.
}

\author{
Ghulam Hussain $^{1}$, Shakeel Ahmad Khan ${ }^{2 *}$, Waqar Ahmad ${ }^{2}$, Makshoof Athar ${ }^{1}$ and Rashid Saleem ${ }^{3}$. \\ 1. Institute of Chemistry, University of the Punjab, Lahore 54590, Pakistan. \\ 2. Department of Chemistry, University of Management and Technology Lahore-54000, Pakistan. \\ 3. Department of Chemistry, GC University, Kachehry Road, Lahore 54000, Pakistan.
}

\section{Manuscript Info}

\section{Manuscript History}

Received: 17 February 2017

Final Accepted: 08 March 2017

Published: April 2017

\section{Key words:-}

Rubazoic acid, Sulphophenyl-methyl pyrazolones, Nitrosation, Reduction

\section{Abstract}

A kinetic study based on spectrophotometric and titrimetric techniques has been carried out for the formation of Rubazoic acid (4E)-4-[(5hydroxy-3-methyl-1-phenyl-4,5-dihydro-1H-pyrazol-4-yl)imino]-5-

methyl-2-phenyl-2,4 dihydro-3H-pyrazol-3-one from 4-amino-1(4sulphophenyl) 3-methyl-2-pyrazolin-5-one. Physicochemical factors like effect of time, $\mathrm{pH}$, aeration and temperature on its formation have been investigated in detail. Elemental analysis, UV-Visible spectral study, FTIR spectral study, ${ }^{1} \mathrm{H}-\mathrm{NMR}$ and ${ }^{13} \mathrm{C}-\mathrm{NMR}$ spectral study was employed for understanding the reaction path way for the formation of rubazoic acid.

Copy Right, IJAR, 2017,. All rights reserved.

\section{Introduction:-}

Rubazoic acid (I) or (4E)-4-[(5-hydroxy-3-methyl-1-phenyl-4,5-dihydro-1H-pyrazol-4-yl)imino]-5-methyl-2phenyl-2,4-dihydro-3H-pyrazol-3-one (I) and its derivatives have been extensively studied. It has several different applications and uses. Kala [1] has reported Rubazoic acid to be used for the photometric determination of nitrogen in organic compounds. Buys Ballot and Steendijk [2] has found rubazoic acid as a useful reagent for determination of ammonia. Shepprad and Houk [3] have utilized rubazoic acid in color photography. A similar application has also been mentioned by Wright [4]. Rubazoic acid derivatives are interesting subject due to their characteristic property of enolic 1,5-diketones in which the $\mathrm{OH}$ participates in a strong hydrogen bond (I). Here observed $\mathrm{O}-\mathrm{O}$ distances are in the range of $2.42-2.45 \mathrm{~A}^{\circ}$, comparable to the shortest values measured in 1,3-diketones (around $2.4 \mathrm{~A}^{\circ}$ ). The special structure generated by the eight-membered $\mathrm{H}$-chelated ring also shows a favorable O-H-O angle for strong hydrogen bonding which is near $180^{\circ} \mathrm{C}$. These $\mathrm{H}$-bonding interactions make Rubazoic acids derivatives as interesting compounds to probe the nature of the proton potential energy profile both in the liquid and solid states. Its formation was at first reported by Knorr ${ }^{5}$ in 1887 who obtained it from 4-amino-1-phenyl-3-methyl-2-pyrazolin5-one using $\mathrm{FeCl}_{3}$ as an oxidizing agent as represented in Fig. 1. Formation of rub-azoic acid from diverse reaction sources have been reported by many workers [6-15]. Knorr [5] and Michaelis [16] reported that rub-azoic Acid on treatment with a strong solution of $\mathrm{NaOH}$ is decomposed to give an open chain product exhibited in Fig. 2. Although rub-azoic Acids of PMP (3-methyl-1-phenyl-2-pyrazolin-5-one) and SPCP (3-carboxy-1-phenyl-2-pyrazolin-5-one) are well known, to our knowledge there is no literature reference which deals with rubazoic acid of SPMP (1(4sulphophenyl) 3-methyl-2-pyrazolin-5-one). In our continuous in the chemistry of pyrazolones, we have undertaken the synthesis and kinetic studies for the formation of rub-azoic acid from SPMP and like to communicate our findings. 
<smiles>CC1=NN(c2ccccc2)C(=O)/C1=N\c1c(C)nn(-c2ccccc2)c1O[In]c1ccccc1</smiles>

Figure 1:-

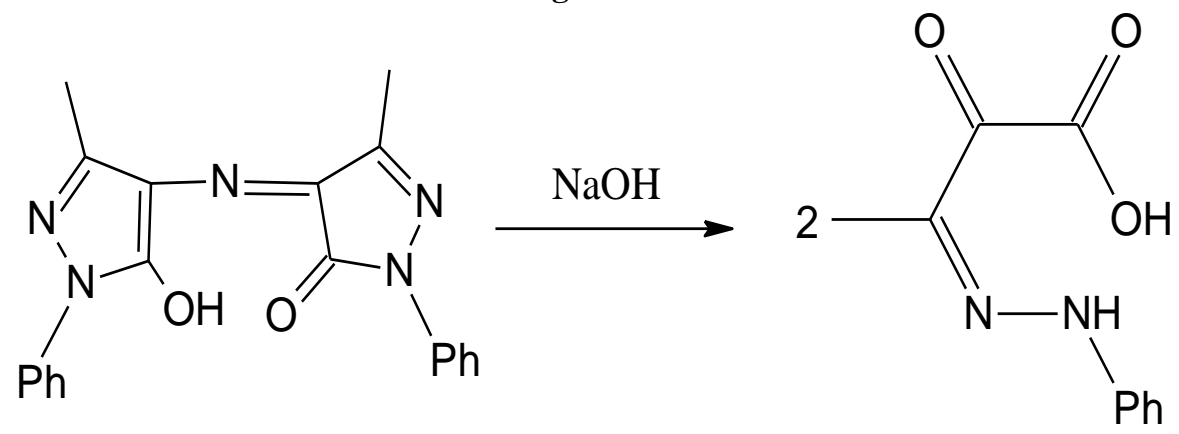

\section{Experimental:-}

Figure 2:- Rubazoic Acid on treatment with a strong solution of $\mathrm{NaOH}$

\section{Materials and Methods:-}

All the chemicals used were purchased from E. Merck, Sigma-Aldrich and were utilized without further purification. The FTIR spectra were recorded on Agilent Carry 630 FTIR Spectrophotometer using Diamond ATR. The spectra are presented in Absorbance mode and frequency from $4000-650 \mathrm{~cm}^{-1}$. UV-visible spectra were measured on Datacolor Spectra-flash SF-550 from 300-700nm.

\section{Synthesis:-}

Step A-Nitrosation of SPMP:-

SPMP (1) (25.4 g, 0.1 mole) was suspended in $\mathrm{H}_{2} \mathrm{O}(250 \mathrm{ml})$. Hydrochloric acid $(45 \mathrm{ml})$ was added to this well stirred suspension. The reaction mixture was cooled to $0-5{ }^{\circ} \mathrm{C}$ in an ice bath. A solution of $\mathrm{NaNO}_{2}(6.9 \mathrm{~g}, 0.1 \mathrm{~mol})$ in $\mathrm{H}_{2} \mathrm{O}(25 \mathrm{ml})$ previously cooled to $0{ }^{\circ} \mathrm{C}$, was then added over a period of 35 minutes with stirring. The stirring was continued for an hour maintaining the same temperature, till positive test for excess nitrous acid. Later on the excess of nitrous ac id was destroyed with required amount of sulphamic acid. The nitroso (Oxime) was filtered after salting out.

\section{Step B: Reduction:-}

The nitroso derivative was reduced by stirring in $200 \mathrm{ml}$ water containing $85 \mathrm{ml} \mathrm{HCl}$ and $23 \mathrm{~g} \mathrm{Zinc} \mathrm{metal} \mathrm{at} \mathrm{boil}$ (103-105 $\left.{ }^{\circ} \mathrm{C}\right)$ to form SPMP amine hydrochloride.

\section{Step C: Diazotization:-}

SPMP amine hydrochloride was diazotized by adding an aqueous solution of $\mathrm{NaNO}_{2}(6.9 \mathrm{~g}$ dissolved in $250 \mathrm{ml}$ of water) and $\mathrm{HCl}$ at -5 to $-2{ }^{\circ} \mathrm{C}$. The nitrous acid formed in situ can diazotize as well as oxidize the amine hydrochloride to rub-azoic acid [5, 18]. Both of the reactions proceeded competitively. The amount of diazonium salt formation was quantified by its coupling reaction with $\beta$-naphthol. The excess of $\beta$-naphthol amount (uncoupled $\beta$-naphthol) was determined by its post coupling with a standard $\mathrm{p}$-nitroaniline diazonium chloride solution. This post coupling value gives the \%age of oxidation of amine of SPMP (\%age of rub-azoic acid formation). H-acid was used as an external indicator in this back titration.

\section{Synthesis of rub-azoic acid derivative of SPMP:-}

After reduction of oxime as described in step B, $\mathrm{pH}$ of the amine solution was raised to 7.5 by $10 \% \mathrm{NaOH}$. Then aeration was carried out to oxidize the amine content to form rubazoic acid [17]. Synthesis of Rubazoic acid from SPMP was carried out according to the scheme sketched in Fig. 3. 


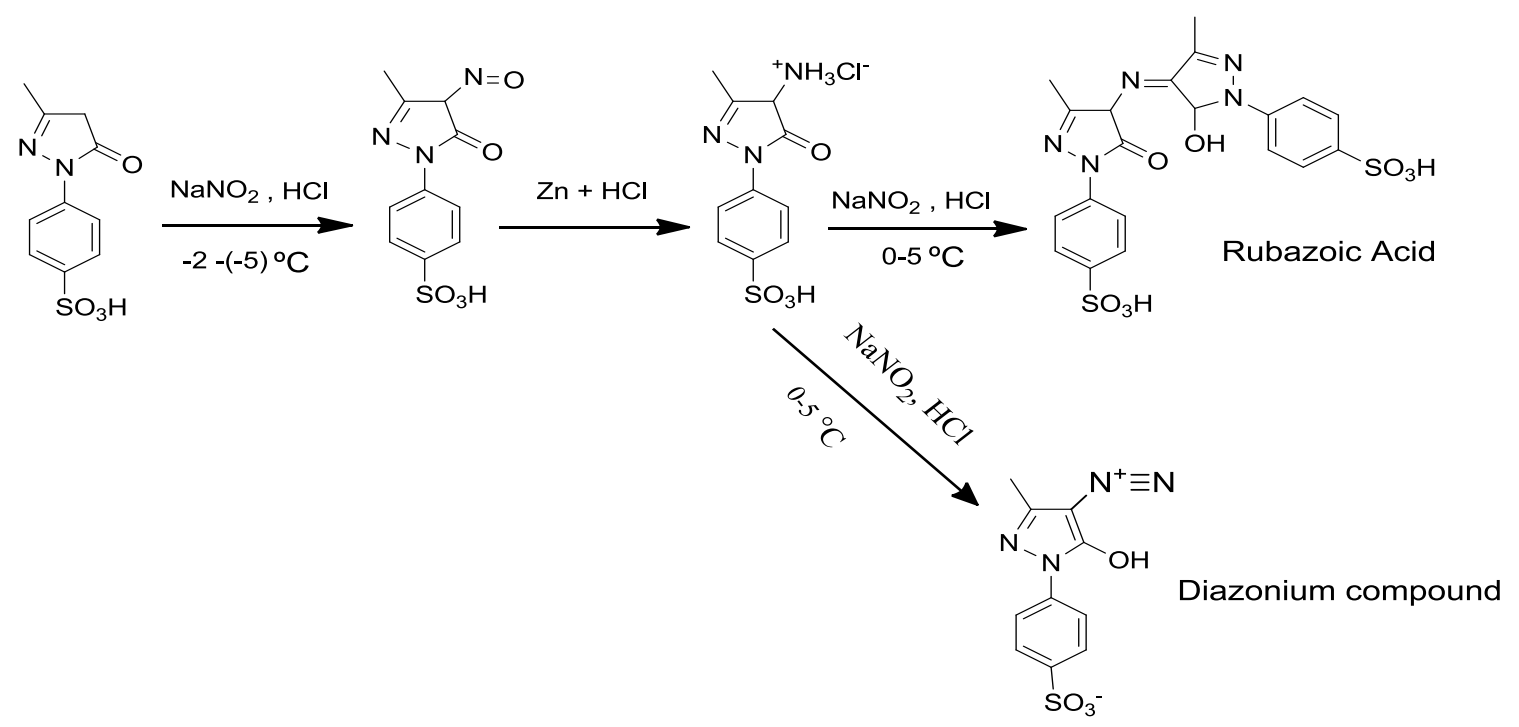

Figure 3:- Scheme for the synthesis of rubazoic acid.

\section{Results and Discussion:-}

Effect of temperature on the synthesis of rub-azoic Acid:-

1(4-sulphophenyl)3-methyl-2-pyrazolin-5-one (SPMP) was nitrosated at $0-5{ }^{\circ} \mathrm{C}$ using $\mathrm{NaNO}_{2}$ and $\mathrm{HCl}$ as described by Knorr ${ }^{5}$. The nitroso compound was filtered to remove some tarry material. The clarified nitroso derivative that usually exists in an oxime form (as indicated by its FTIR), was salted out by common salt and dried after filtration. Reduction of nitrso/oxime of SPMP was carried in two ways. Low temperature reduction (B1 process) of oxime was carried out at $0-5{ }^{\circ} \mathrm{C}$ using Zinc and $\mathrm{NH}_{4} \mathrm{Cl}$ as pointed out by Nies [13]. The process resulted in the formation of both rubazoic acid of SPMP and its amine. High temperature reduction (B2 Process) of oxime of SPMP was carried at $100-105^{\circ} \mathrm{C}$ using Zinc and $\mathrm{HCl}$. A mixture of water and $\mathrm{HCl}$ (3:1) was heated to boiling. The oxime of SPMP and zinc metal were added in small portions at boil. The reduction was completed as the solution became colorless. A small amount of additional zinc was added and the resultant amine hydrochloride was quenched to $-7^{\circ} \mathrm{C}$. The excessive un-reacted zinc was removed by filtration. The comparative results of the both processes for the formation of SPMP amine hydrochloride and Rub-azoic acid are presented in Table 1.

Table 1:- Reduction of Nitroso/Oxime of SPMP.

\begin{tabular}{|l|l|l|l|l|l|l|l|}
\hline Process & Oxime $(\mathrm{g})$ & Zn used $(\mathrm{g})$ & NH4Cl $(\mathrm{g})$ & Temp $\left({ }^{\circ} \mathrm{C}\right)$ & $\begin{array}{l}\mathrm{HCl} \\
(\mathrm{ml})\end{array}$ & $\begin{array}{l}\text { Amine } \\
(\%)\end{array}$ & $\begin{array}{l}\text { Rubazoic acid } \\
(\%)\end{array}$ \\
\hline B-1 & 28.3 & 7.8 & 8 & $3-5$ & 45 & $85-86$ & $24-25$ \\
\hline B-2 & 28.3 & 23 & 0 & $100-105$ & 85 & $97-98$ & $2-3$ \\
\hline
\end{tabular}

Note: - Amine content was determined by $1^{\text {st }}$ Coupling value and Rubazoic acid by Post coupling value.

Effect of nitrite addition time on diazotization during synthesis of Rubazoic acid:-

Series of experiments were performed to study the effect of addition time of sodium nitrite solution to evaluate the \%age of diazotization of SPMP amine hydrochloride and its \%age of oxidation to Rubazoic acid derivative formation. The addition time of sodium nitrite was varied from one time addition to 255 minutes duration. The comparative formation of diazonium compound of SPMP and rubazoic acid is given in Table 2. Figure 4 is the graphical representation of the data given in Table 2, showing the comparative oxidizing and diazotizing effect of nitrous acid on SPMP amine hydrochloride. 


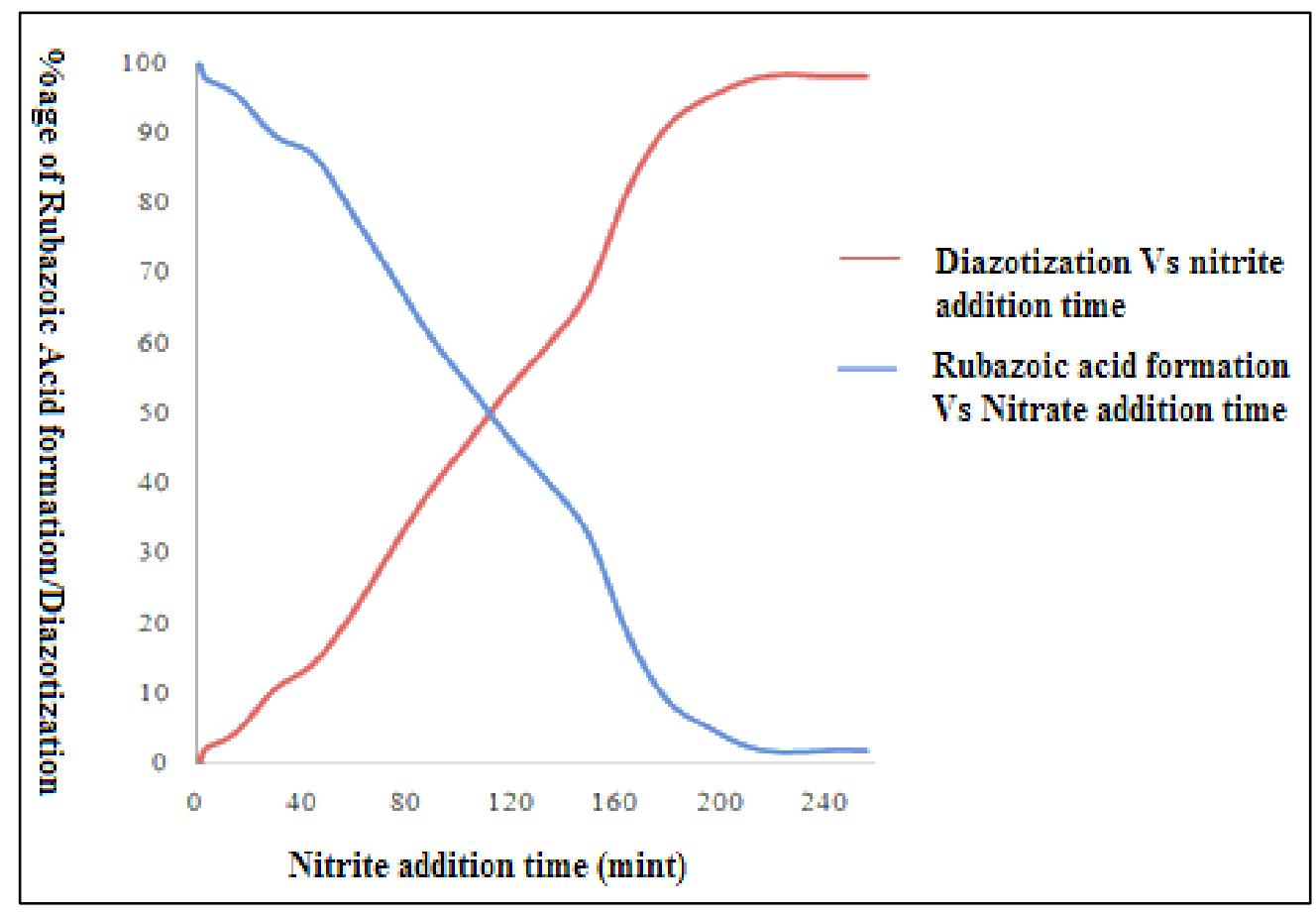

Figure 4:- Comparative formation of Diazonium compound of SPMP and Rubazoic acid

Table 2:- The comparative formation of diazonium compound of SPMP and Rubazoic acid.

\begin{tabular}{|c|c|c|c|c|c|c|c|c|c|}
\hline $\begin{array}{l}\text { Sr. } \\
\text { No. }\end{array}$ & $\begin{array}{l}\text { Nitrite } \\
\text { addition } \\
\text { time (mint.) }\end{array}$ & $\begin{array}{l}\text { SPMP } \\
\text { amine } \\
\text { (moles } \\
\text { ) }\end{array}$ & $\begin{array}{l}\text { Couple } \\
\mathrm{r} \\
\text { (moles) }\end{array}$ & $\begin{array}{l}\text { Couplin } \\
\text { g } \\
\mathrm{Ph}\end{array}$ & $\begin{array}{l}\text { Coupling } \\
\text { Temp } \\
\left({ }^{\circ} \mathrm{C}\right)\end{array}$ & $\begin{array}{l}\% \text { of } \\
\text { Coupler } \\
\text { Coupled }\end{array}$ & $\begin{array}{l}\% \text { of } \\
\text { Coupler, } \\
\text { Uncouple } \\
\mathrm{d}\end{array}$ & $\begin{array}{l}\text { Diazotizatio } \\
\text { n } \\
\%\end{array}$ & \begin{tabular}{ll}
\multicolumn{3}{l}{ Rubazoi } \\
c & acid \\
$\%$ &
\end{tabular} \\
\hline 1 & 1 (once) & 0.1 & 0.1 & $8.5-9.5$ & $5-15$ & zero & 100 & Zero & 100 \\
\hline 2 & 3 (Twice) & 0.1 & 0.1 & $8.5-9.5$ & $5-15$ & 2 & 98 & 2 & 98 \\
\hline 3 & 5 (Thrice) & 0.1 & 0.1 & $8.5-9.5$ & $5-15$ & 2.5 & 97.5 & 2.5 & 97.5 \\
\hline 4 & 15 & 0.1 & 0.1 & $8.5-9.5$ & $5-15$ & 4.5 & 95.5 & 4.5 & 95.5 \\
\hline 5 & 30 & 0.1 & 0.1 & $8.5-9.5$ & $5-15$ & 10.6 & 89.4 & 10.6 & 89.4 \\
\hline 6 & 45 & 0.1 & 0.1 & $8.5-9.5$ & $5-15$ & 14.3 & 86.7 & 14.3 & 86.7 \\
\hline 7 & 60 & 0.1 & 0.1 & $8.5-9.5$ & $5-15$ & 21.8 & 78.2 & 21.8 & 78.2 \\
\hline 8 & 75 & 0.1 & 0.1 & $8.5-9.5$ & $5-15$ & 30.7 & 69.3 & 30.7 & 69.3 \\
\hline 9 & 90 & 0.1 & 0.1 & $8.5-9.5$ & $5-15$ & 39.3 & 60.7 & 39.3 & 60.7 \\
\hline 10 & 105 & 0.1 & 0.1 & $8.5-9.5$ & $5-15$ & 46.4 & 53.6 & 46.4 & 53.6 \\
\hline 11 & 120 & 0.1 & 0.1 & $8.5-9.5$ & $5-15$ & 53.8 & 46.2 & 53.8 & 46.2 \\
\hline 12 & 135 & 0.1 & 0.1 & $8.5-9.5$ & $5-15$ & 60.1 & 39.9 & 60.1 & 39.9 \\
\hline 13 & 150 & 0.1 & 0.1 & $8.5-9.5$ & $5-15$ & 67.6 & 32.4 & 67.6 & 32.4 \\
\hline 14 & 165 & 0.1 & 0.1 & $8.5-9.5$ & $5-15$ & 81.8 & 18.2 & 81.8 & 18.2 \\
\hline 15 & 180 & 0.1 & 0.1 & $8.5-9.5$ & $5-15$ & 90.9 & 9.1 & 90.9 & 9.1 \\
\hline 16 & 195 & 0.1 & 0.1 & $8.5-9.5$ & $5-15$ & 94.8 & 5.2 & 94.8 & 5.2 \\
\hline 17 & 210 & 0.1 & 0.1 & $8.5-9.5$ & $5-15$ & 97.5 & 2.5 & 97.5 & 2.5 \\
\hline 18 & 225 & 0.1 & 0.1 & $8.5-9.5$ & $5-15$ & 98.3 & 1.7 & 98.3 & 1.7 \\
\hline 19 & 240 & 0.1 & 0.1 & $8.5-9.5$ & $5-15$ & 98 & 2 & 98 & 2 \\
\hline 20 & 255 & 0.1 & 0.1 & $8.5-9.5$ & $5-15$ & 98 & 2 & 98 & 2 \\
\hline
\end{tabular}


Spectrophotometric Study for the formation of SPMP Rubazoic acid derivative from SPMP amine hydrochloride:-

At pH 7.0 or above SPMP amine is automatically converted into Rubazoic acid and its strength gradually increases as a function of time. To measure the strength of Rubazoic acid, the spectrophotometric cell was filled with solution of the amine $(2.0 \mathrm{mM})$ and the initial reading was taken as standard. The same solution remained in the measuring compartment of the instrument and readings were taken as a function of time till maximum or constant strength. This procedure was repeated for every $\mathrm{pH}$ variant. The results of rub-azoic acid formation and its strength measurements with respect to $\mathrm{pH}$ and Time are presented in Table 3. The graphical presentation of Rubazoic acid formation of the data as presented in Table 3 is shown in Figure 5. The absorption spectrum of Rubazoic acid formation at different time intervals at constant $\mathrm{pH} 7.5$ is shown in Figure 6.

Table 3:- Spectrophotometric study for the formation of Rubazoic acid and its strength as a function of time from SPMP amine at different $\mathrm{pH}$ values

\begin{tabular}{|l|l|l|l|l|l|l|l|l|}
\hline Time $(\mathrm{min})$ & $\mathrm{pH}=7.0$ & $\mathrm{pH}=7.5$ & $\mathrm{pH}=8.0$ & $\mathrm{pH}=8.5$ & $\mathrm{pH}=9.0$ & $\mathrm{pH}=9.5$ & $\mathrm{pH}=10.0$ & $\mathrm{pH}=10.5$ \\
\hline 0 & 0 & 0 & 0 & 0 & 0 & 0 & 0 & 0 \\
\hline 5 & 20.54 & 30.33 & 73.76 & 82.04 & 105 & 135.1 & 360.2 & 400.39 \\
\hline 10 & 48.51 & 68.63 & 122.69 & 195.46 & 320.4 & 386.2 & 450.65 & 475.76 \\
\hline 15 & 96.83 & 138.51 & 230.52 & 250.5 & 430.15 & 455.63 & 500 & 490.1 \\
\hline 20 & 118.25 & 193.77 & 340.67 & 448.9 & 480.26 & 490.52 & 510.23 & 480.23 \\
\hline 25 & 158.32 & 215.36 & 419.74 & 473.15 & 495.66 & 503.26 & 503.45 & 456.36 \\
\hline 30 & 198.46 & 340.84 & 447.57 & 486.93 & 506.08 & 515.63 & 495.61 & 430.48 \\
\hline 35 & 240.15 & 366.9 & 453.32 & 493.97 & 506.9 & 516.12 & 479.35 & 419.56 \\
\hline 40 & 281.35 & 398.15 & 457.32 & 500.26 & 510.34 & 518.96 & 468.52 & 405.55 \\
\hline 50 & 319.1 & 417.4 & 457.77 & 508.16 & 511.95 & 519.6 & 460.13 & 365.12 \\
\hline 60 & 344.64 & 428.05 & 459.25 & 510.45 & 513035 & 520.24 & 459.2 & 350.4 \\
\hline 70 & 370.36 & 431.96 & 460.5 & 512.3 & 517.96 & 521.86 & 458.56 & 330.94 \\
\hline 80 & 381.86 & 432.76 & 462.68 & 513.36 & 520.4 & 522.9 & 457.96 & 322.6 \\
\hline 100 & 406.6 & 435.5 & 463.59 & 515.34 & 521.23 & 523.1 & 456.85 & 300.54 \\
\hline 110 & 410.4 & 437.66 & 465.33 & 515.96 & 522 & 524.2 & 456.32 & 298.64 \\
\hline 120 & 412.6 & 438.9 & 466.1 & 516.26 & 522.6 & 524.1 & 456 & 295.28 \\
\hline 150 & 413.5 & 439 & 466.53 & 516.46 & 522.7 & 524 & 455.65 & 293.61 \\
\hline 180 & 414.11 & 439.5 & 46.83 & 516.6 & 522.76 & 523.86 & 455.23 & 292.1 \\
\hline 210 & 415.46 & 439.52 & 466.89 & 516.76 & 522.78 & 523.46 & 455 & 291.86 \\
\hline
\end{tabular}

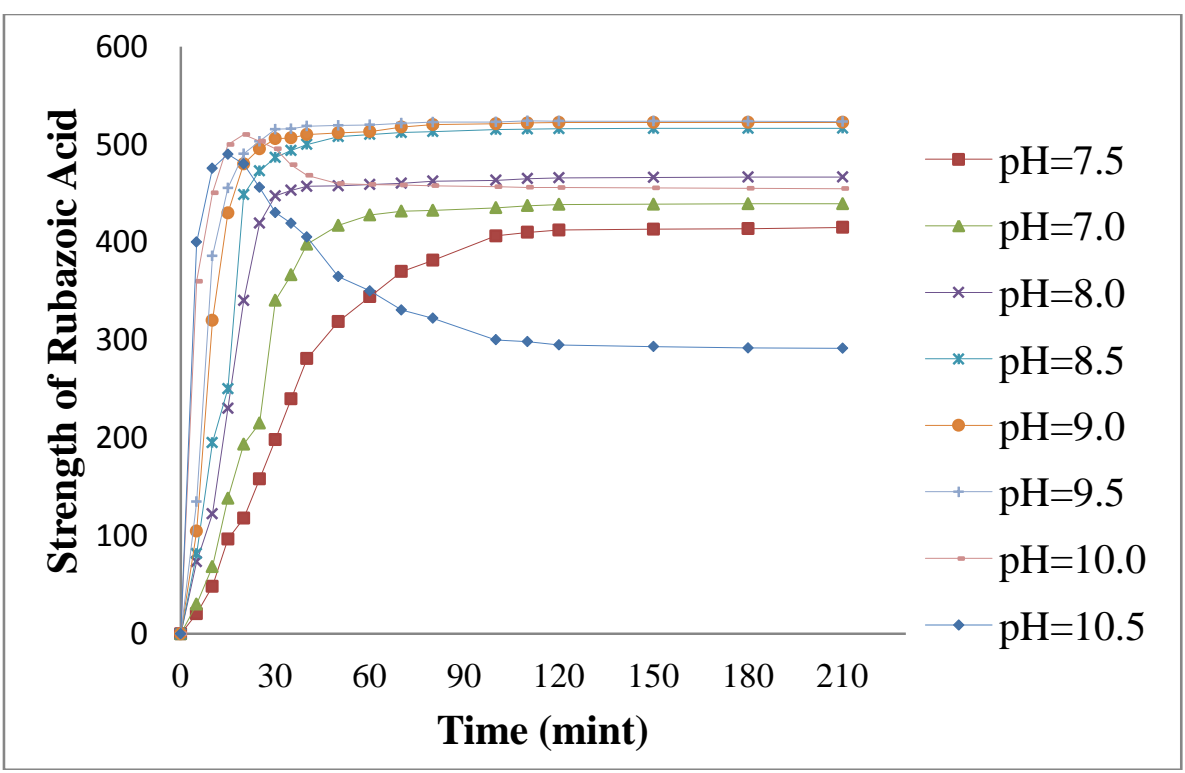

Figure 5:- Formations of rubazoic acid and its strength as a function of time from SPMP amine at different $\mathrm{pH}$ values. 


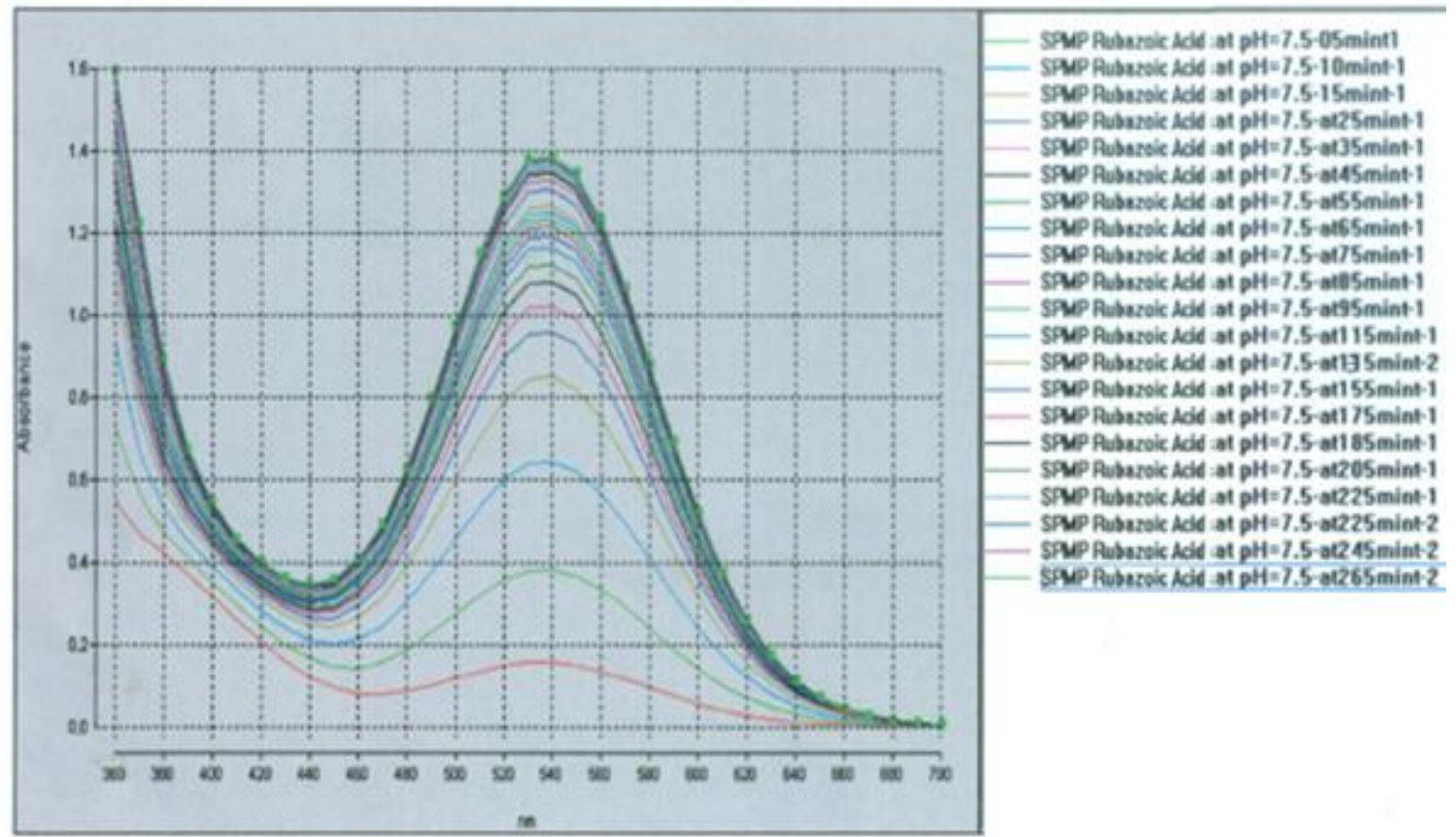

Figure 6:- UV-Visible spectrums for the formation of rubazoic acid derivative of SPMP at pH 7.5

\section{Isolation and study of stability of Diazonium compound of SPMP:-}

The diazonium compound of SPMP was salted out by the addition of common salt to obtain diazonium compound as yellow color needles. Filtration and freeze drying gave a stable diazonium compound in dry form*. In wet paste, it has been found to be active even after five months and in its dry state it was equally good after two months as found by its coupling with $\beta$-naphthol and resorcinol. *A word of caution: although this diazonium salt seems to be quite stable, both in the dry and the wet state, at room temperature for a few months, it should be handled with all the precautions of a potentially hazrdous substance as diazonium salts are known to be.

\section{FTIR spectral study for reaction path way:-}

FTIR study of SPMP showed its enolic OH at $3166 \mathrm{~cm}^{-1}, \mathrm{C}=\mathrm{C}$ bond at $1591 \mathrm{~cm}^{-1}$ and $\mathrm{S}=\mathrm{O}$ at $1183 \mathrm{~cm}^{-1}$. On nitrosation the enolic group of the parent compound was converted to ketonic carbonyl as shown by its signal at $1716 \mathrm{~cm}^{-1}(\mathrm{C}=\mathrm{O})$ and $\mathrm{C}=\mathrm{N}$ stretch at $1595 \mathrm{~cm}^{-1}$ indicating that it is in oxime form. Diazotization resulted in the reappearance of enolic $\mathrm{OH}$ at $3416 \mathrm{~cm}^{-1}$ and a new signal for triply bonded nitrogen at $2124 \mathrm{~cm}^{-1}$. Coupling of diazonium compound with $\beta$-naphthol resulted into the formation of an orange dye and disappearance of triple bond signal at $2124 \mathrm{~cm}^{-1}$ confirming coupling, also shown by FTIR of the dye. Figure 7 (a-e) depicts the FTIR spectra of the products at various steps, thus enabling a clear characterization of the changes through the disappearance of specific absorption bands of the groups modified/changed during the reaction process. This work was started from nitrosation of 1(4-sulphophenyl) 3-methyl-2-pyrazolin-5-one (SPMP), Reduction of nitroso derivative, diazotization, coupling with $\beta$ - naphthol and post-coupling of uncoupled $\beta$-naphthol with a standard diazonium compound of $p$ nitroaniline. 

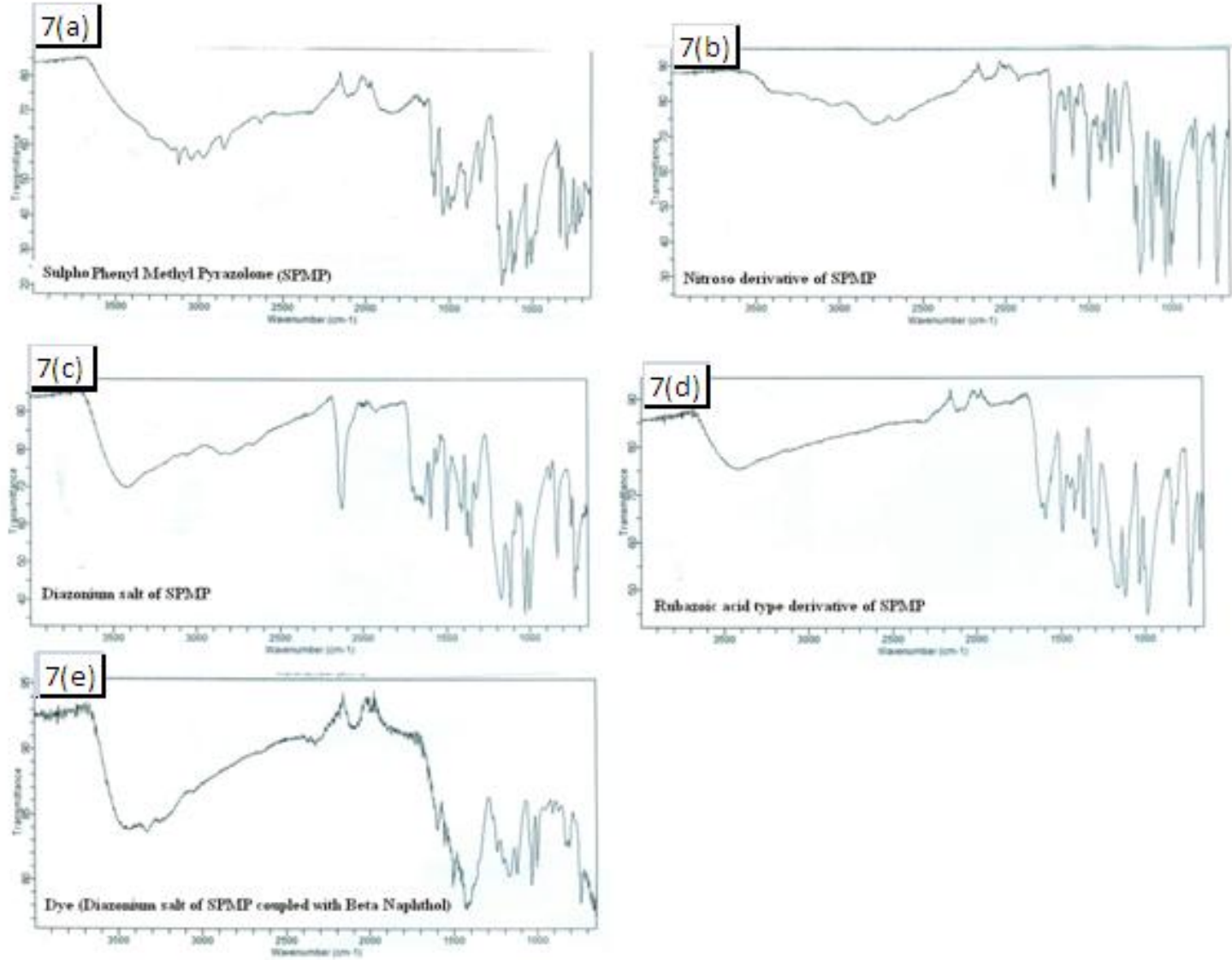

Figure 7:- 7(a): FTIR spectrum of sulphophenyl methyl pyrazolone (SPMP); 7(b): FTIR spectrum of oxime derivative of SPMP; 7(c): FTIR spectrum of diazonium compound of SPMP, 7(d): FTIR spectrum of Rubazoic acid derivative; 7(e): FTIR spectrum of dye formed by the coupling of $\beta$ - naphthol with SPMP diazonium derivative.

NMR spectral data of Rubazoic acid:-

Proton NMR spectral data for the rub-azoic acid was ${ }^{1} \mathrm{H}-\mathrm{NMR}\left(\mathrm{CDCl}_{3}\right) \mathrm{g}$ at $(11.95$, s $2 \mathrm{H}) \mathrm{SO}_{3} \mathrm{H},(6.88-8.09, \mathrm{~m} 8 \mathrm{H})$ $\mathrm{ArH},(1.94-2.31, \mathrm{~s} 6 \mathrm{H}) \mathrm{CH}_{3},(1.8-4.4, \mathrm{~s} 2 \mathrm{H}) \mathrm{CH},(3.65, \mathrm{~s} 1 \mathrm{H}) \mathrm{OH}$. There was founded a singlet peak at $11.95 \mathrm{MHz}$ of 2 hydrogens which confirmed the presence of Sulfonic group $\left(\mathrm{SO}_{3} \mathrm{H}\right)$. Multiplet peaks of eight aromatic hydrogens observed at 6.88-8.09 MHz while singlet peak at 3.65 observed for $\mathrm{CH}_{3}$. Methyl group peak observed at this frequency due to electron withdrawing effect which makes it more deshielded. This deshielding effect was experienced by $\mathrm{CH}_{3}$ group because it is substituted at that carbon which was doubly bonded with nitrogen. Singlet of two hydrogens was observed at peaks $1.8 \mathrm{MHz}$ and $4.4 \mathrm{MHz}$ for $\mathrm{CH}$ group. These NMR signals for $\mathrm{CH}$ group observed downfield in comparison to normal position because of the electron withdrawing effect of neighboring atoms like Nitrogen and Oxygen in five membered ring which make it more deshielded. Singlet peak of $1 \mathrm{H}$ for alcoholic hydroxyl group was obtained at $3.65 \mathrm{MHz}$.

Obtained ${ }^{13} \mathrm{C}$ NMR spectral data for the rub-azoic acid was ${ }^{13} \mathrm{C}-\mathrm{NMR}$ : 11.93-15.9 $\left(\mathrm{CH}_{3}\right), 84.7(\mathrm{CH}), 157.5(\mathrm{C}=\mathrm{O})$, 114.8, 121.4, 126.7, 127.3, 137.6, 144.1, 144.8, 147.6 (Aromatic carbons).

\section{Elemental Analysis of Rubazoic acid:-}

Elemental analysis of synthesized rub-azoic acid which was C (46.06 \%), H (3.67 \%), N (13.43\%), O (24.54 \%), S $(12.30 \%)$ affirmed and authenticated the synthetic scheme of rub-azoic acid formation represented in Fig. 3. Practical elemental analysis of rub-azoic acid find in close agreement with the calculated elemental analysis of rubazoic acid. Hence it's cleared the formation of rub-azoic acid. 


\section{Conclusion:-}

In this work it was founded and affirmed from Elemental analysis, UV-Visible spectral data, FTIR spectral data, ${ }^{1} \mathrm{H}-$ NMR and ${ }^{13} \mathrm{C}$-NMR spectral data of rub-azoic acid type derivative of SPMP that rub-azoic acid is formed in water automatically at $\mathrm{pH} 7.0$ or above. The amine hydrochloride of SPMP was found to be stable at $-7^{\circ} \mathrm{C}$. The optimum diazotization temperature for this amine has been found to be -5 to $-3{ }^{\circ} \mathrm{C}$. At a temperature, above this range, amine hydrochloride is oxidized by air or nitrous acid to form rub-azoic acid. Rub-azoic acid of SPMP is formed at a greater rate at higher $\mathrm{pH}$ as well. At $\mathrm{pH} 10$ or above it starts to deteriorate, as indicated by the above data. The higher rate of nitrite addition formed greater amount of nitrous acid that favored the formation of rub-azoic acid, while a slow addition of nitrite leads to greater \%age of diazotization. The diazonium compound of SPMP has been isolated and found to be stable in dry form like that of 1-amino-2 naphthol-4-sulfonic acid (1,2,4-Acid $)^{15}$. Moreover its sluggish coupling behavior also indicated its internal salt nature. FTIR spectrum confirmed its nature as indicated

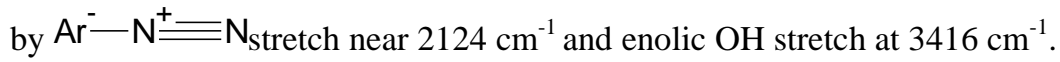

\section{Acknowledgments:-}

We gratefully acknowledge the assistance of specialty chemicals manufacturing company, SRC (PVT) LTD. for providing research facilities at its $R \& D$ lab.

\section{References:-}

1. Kala H (1963): Die Pharmazie, On the photometric determination of nitrogen in organic compounds by the rubazonic acid method. 18-21 29.

2. AB Ballot, C Steendijk (1965): Clinica Chimica Acta, Ammonia determination in a trichloroacetic acid blood filtrate after microdiffusion with the aid of the rubazonic acid reaction 55-62 12(1).

3. SE Sheppard, RC Houck (1940): Photographic antihalation layer, US, 2203659.

4. PJ Wrigth, (1978): Quaternary ammonium polymers and photographic materials containing same US, 4108802.

5. L Knorr, (1887): Justus Liebigs Ann. Chem, Synthetische Versuche mit dem Acetessigester 238-243 137.

6. T Curtius, (1992) J P rakt Chem, Chemistry of Heterocyclic Compounds, Pyrazolones, Pyrazolidones, and Derivatives, 85, 37.

7. ED Bergmann, D Ginsburg, R Pappo, (2011): Organic Reactions, The Michael Reaction, 179-556 10(3).

8. A Heiduschka, O Rothacker, (1911): J Fur Pr Chem, synthesis of 1-phenyl-3-methyl-4-amino-fi-pyrazolone, 534-53784.

9. W Wislicnus, H Goz, (1911): Conversion of the Nitro- into the Keto-group, Ber, 3491-3496 44.

10. A Wahl, M Doll, (1913): Reactions of @-Diketonic Esters, Bull. Soc. Chim. Franc, 468-475 13.

11. E Votocek, O Wichterle, (1935): Collection Czechoslov Commun, 4-(5-Hydroxy-4-pyrazolylimino)-2pyrazolin-5-one und ihre Metallchelate, Synthese von 4-(5-Hydroxy-4-pyrazolylimino)-2-pyrazolin-5-onen (Rubazonsäuren) und strukturanalogen Verbindungen, 388-393 7.

12. M Freri, (1936): Gaz Chim Ital, Chemistry of Heterocyclic Compounds: Pyrazolones, Pyrazolidones, and Derivatives, 1498-1502 23.

13. AB Nies, BNJ Brook, (1947): Diazo compounds of the pyrazolone. US, 2420791.

14. H Gysling, G Schwarzenbach, (1949): Hel Chim Acta, Spectrophotometric Determination of Magnesium, Calcium, Strontium and Barium Present in Pairs by Use of Tetramethylmurexide 1484-1488, 32.

15. GF Duffin, JD Kendall, (1955); J Chem Soc, Chemistry of Heterocyclic Compounds: Triazoles 1,2,4, 3669$3673,2$.

16. G Michaelis, F Wrede, (1907): Ann. Reactive intermediates in the photochemistry of 4-diazo-2-pyrazolin-5ones, 352-356, 152.

17. G Westoo, (1965): Acta Chem Scand, On the Metabolism of Tartrazine in the Rat. 1309-1309, 19.

18. CS Rondestvedt, PK Chang, (1955): J Am Chem Soc, Pechmann Pyrazole Synthesis. 6532-6536, 77.

19. HE Fierz-David, L Blangey, (1949): Interscience Publishers Inc London Fundamental Process of Dye Chemistry, 1-253 2. 